\title{
New therapeutic approaches for treatment of tularaemia: a review
}

\author{
Sandrine Boisset ${ }^{1,2,3}$, Yvan Caspar ${ }^{1,2,3}$, Vivien Sutera ${ }^{1,2,3}$ and Max Maurin ${ }^{1,2,3}$ \\ ' Laboratoire de Bactériologie, Institut de Biologie et de Pathologie, CHU de Grenoble, Grenoble, France \\ ${ }^{2}$ Université Joseph Fourier-Grenoble 1, Grenoble, France \\ ${ }^{3}$ Laboratoire Adaptation et Pathogénie des Micro-Organismes, CNRS/UJF, UMR 5163, Grenoble, France
}

\section{Edited by:}

Didier Raoult, Université de la

Méditerranée, France

Reviewed by:

William Picking, Oklahoma State

University, USA

Vincent Joseph Starai, The

University of Georgia, USA

\section{*Correspondence:}

Sandrine Boisset, Laboratoire de Bactériologie, Centre Hospitalier Universitaire Grenoble, Institut de Biologie et de Pathologie, CS10217, 38043 Grenoble cedex 9, France e-mail: sboisset@chu-grenoble.fr
Antibiotic treatment of tularaemia is based on a few drugs, including the fluoroquinolones (e.g., ciprofloxacin), the tetracyclines (e.g., doxycycline), and the aminoglycosides (streptomycin and gentamicin). Because no effective and safe vaccine is currently available, tularaemia prophylaxis following proven exposure to $F$. tularensis also relies on administration of antibiotics. A number of reasons make it necessary to search for new therapeutic alternatives: the potential toxicity of first-line drugs, especially in children and pregnant women; a high rate of treatment relapses and failures, especially for severe and/or suppurated forms of the disease; and the possible use of antibiotic-resistant strains in the context of a biological threat. This review presents novel therapeutic approaches that have been explored in recent years to improve tularaemia patients' management and prognosis. These new strategies have been evaluated in vitro, in axenic media and cell culture systems and/or in animal models. First, the activities of newly available antibiotic compounds were evaluated against $F$. tularensis, including tigecycline (a glycylcycline), ketolides (telithromycin and cethromycin), and fluoroquinolones (moxifloxacin, gatifloxacin, trovafloxacin and grepafloxacin). The liposome delivery of some antibiotics was evaluated. The effect of antimicrobial peptides against $F$. tularensis was also considered. Other drugs were evaluated for their ability to suppress the intracellular multiplication of $F$. tularensis. The effects of the modulation of the innate immune response (especially via TLR receptors) on the course of $F$. tularensis infection was characterized. Another approach was the administration of specific antibodies to induce passive resistance to $F$. tularensis infection. All of these studies highlight the need to develop new therapeutic strategies to improve the management of patients with tularaemia. Many possibilities exist, some unexplored. Moreover, it is likely that new therapeutic alternatives that are effective against this intracellular pathogen could be, at least partially, extrapolated to other human pathogens.

Keywords: tularaemia, treatment, antibiotics, immunotherapy, antibodies

\section{INTRODUCTION}

Francisella tularensis, the agent of tularaemia, is a facultative intracellular pathogen of humans and hundreds of animal species (including mammals, insects, arthropods, and protozoa). It is highly infectious, with only 10 bacteria able to cause a lethal infection. Two F. tularensis subspecies are virulent for humans: subsp. tularensis (type A), found mainly in North America, and subsp. holarctica (type B), found throughout the northern hemisphere. Both subspecies are classified as category A agents of biological threat by the Centers for Disease Control (CDC, Atlanta, Georgia, USA).

Tularaemia is considered a re-emerging disease, and recent outbreaks have been reported worldwide (Chitadze et al., 2009; Hauri et al., 2010). The mean incubation period of tularaemia is only 3-5 days (Tarnvik and Chu, 2007) and even less in case of aerosol contamination. Most clinical cases involve chronic lymphadenopathy associated with a skin, mucosa or conjunctival inoculation lesion. Less frequently, patients suffer from systemic diseases, and inhalation of infected aerosols may lead to severe pneumonia with mortality rates up to $60 \%$ (Gill and Cunha, 1997). This latter clinical form is the most feared in the context of bioterrorism. No vaccine is currently available and only a few antibiotic classes are effective to treat tularaemia patients, including the fluoroquinolones, the tetracyclines and the aminoglycosides (only streptomycin and gentamicin) (KuoLee and Chen, 2007; Hepburn and Simpson, 2008). Although no acquired resistance to these antibiotics has been described in natural strains of $F$. tularensis, many therapeutic failures and relapses have been reported (Perez-Castrillon et al., 2001; Kosker et al., 2013). Even with antibiotic treatment, tularaemia may be associated with $2 \%$ mortality (Evans et al., 1985). It is therefore essential to develop novel and effective preventive and curative treatments.

We will review the current therapeutic approaches and new therapeutic strategies (Table 1) published in the English literature. 
Table 1 | New therapeutic alternatives evaluated against $F$ tularensis infection.

\begin{tabular}{|c|c|c|c|}
\hline Drug & Mechanism of action/target & Activity on $F$ tularensis & References \\
\hline \multicolumn{4}{|c|}{ NEW ANTIBIOTICS } \\
\hline Ketolides & $\begin{array}{l}\text { Inhibit protein synthesis by interacting with the } \\
\text { peptidyl-transferase site of the bacterial } 50 \mathrm{~S} \\
\text { ribosomal subunit. }\end{array}$ & $\begin{array}{l}\text { Effective in vitro against French isolates of } \\
\text { F. tularensis subsp. holarctica }\end{array}$ & Gestin et al., 2010 \\
\hline Tigecycline & $\begin{array}{l}\text { Inhibits protein translation by binding to the } \\
30 \text { S ribosomal subunit and blocking entry of } \\
\text { amino-acyl tRNA molecules into the A site of } \\
\text { the ribosome }\end{array}$ & $\begin{array}{l}\text { Effective in vitro against Hungarian F. tularensis } \\
\text { subsp. holarctica }\end{array}$ & $\begin{array}{l}\text { Kreizinger et al., } \\
2013 b\end{array}$ \\
\hline $\begin{array}{l}\text { Grepafloxacin } \\
\text { Trovafloxacin } \\
\text { Sparfloxacin } \\
\text { Gatifloxacin }\end{array}$ & $\begin{array}{l}\text { Inhibit DNA synthesis by targeting DNA gyrase } \\
\text { and topoisomerases }\end{array}$ & $\begin{array}{l}\text { Highly active in vitro against American and } \\
\text { Austrian F. tularensis subsp. tularensis and } \\
\text { subsp. holarctica strains } \\
\text { Gatifloxacin effective in vivo in a BALB/c } \\
\text { mouse model of F. tularensis Schu S4 infection }\end{array}$ & $\begin{array}{l}\text { Ikaheimo et al., } 2000 \\
\text { Johansson et al., } \\
2002 \\
\text { Tomaso et al., } 2005 \\
\text { Piercy et al., 2005; } \\
\text { Steward et al., } 2006\end{array}$ \\
\hline Linezolide & $\begin{array}{l}\text { Inhibits the initiation process of protein } \\
\text { synthesis }\end{array}$ & $\begin{array}{l}\text { Effective in vitro against Turkish strains, } \\
\text { Not effective against } F \text {. tularensis strains } \\
\text { isolated in Hungary or in North America }\end{array}$ & $\begin{array}{l}\text { Yesilyurt et al., } 2011 \\
\text { Johansson et al., } \\
2002\end{array}$ \\
\hline \multicolumn{4}{|c|}{ ANTIMICROBIAL PEPTIDE } \\
\hline LL-37 & $\begin{array}{l}\text { Stimulates the innate immune response, } \\
\text { increases in the production of IL-6, II-12, } \\
\text { IFN-gamma, and MCP-1 }\end{array}$ & $\begin{array}{l}\text { Moderately and transiently effective in a } \\
\text { murine model of LVS-induced pneumonia }\end{array}$ & $\begin{array}{l}\text { Flick-Smith et al., } \\
2013\end{array}$ \\
\hline \multicolumn{4}{|c|}{ OTHER MODULATOR OF INNATE IMMUNE RESPONSE } \\
\hline $\mathrm{IL}-12$ & $\begin{array}{l}\text { Activates Th1 and NK cells and induces the } \\
\text { production of IFN-gamma }\end{array}$ & $\begin{array}{l}\text { Improves the clinical outcome and survival of } \\
\text { animals infected with F. novicida, when } \\
\text { co-administrated with gentamicin. }\end{array}$ & $\begin{array}{l}\text { Pammit et al., } 2004 \\
\text { Kirimanjeswara } \\
\text { et al., } 2008\end{array}$ \\
\hline
\end{tabular}

\begin{tabular}{|c|c|c|c|}
\hline AGP & $\begin{array}{l}\text { Synthetic TLR4 agonist, increases the amount } \\
\text { of intrapulmonary cytokines and chemokines }\end{array}$ & $\begin{array}{l}\text { Reduced bacterial replication in the lungs, liver } \\
\text { and spleen, and increased survival of animals } \\
\text { infected with F. novicida }\end{array}$ & Lembo et al., 2008 \\
\hline CpG & $\begin{array}{l}\text { TLR9 activator, indirectly activates NK cells } \\
\text { resulting in cytokines and NO production }\end{array}$ & $\begin{array}{l}\text { Better survival of mice infected with } F \\
\text { tularensis LVS, but no effect in mice with } F \\
\text { tularensis SCHU4 pneumonia }\end{array}$ & $\begin{array}{l}\text { Elkins et al., } 2009 \\
\text { Rozak et al., } 2010\end{array}$ \\
\hline poly $(l: C)$ & $\begin{array}{l}\text { Synthetic double stranded RNA analog, TLR3 } \\
\text { activator, induces an early and effective innate } \\
\text { immune response }\end{array}$ & $\begin{array}{l}\text { Better survival of mice infected with } F \\
\text { tularensis LVS or Schu S4 } \\
\text { Reduction in replication of } F \text {. tularensis within } \\
\text { human monocyte-derived macrophages }\end{array}$ & Pyles et al., 2010 \\
\hline Galantamine & $\begin{array}{l}\text { Influences the immune response via the } \\
\text { cholinergic anti-inflammatory pathway by } \\
\text { up-regulating IFN-gamma production and } \\
\text { down-regulating IL-6 production }\end{array}$ & $\begin{array}{l}\text { Reduced mortality rates in mice infected with } \\
\text { F. tularensis LVS }\end{array}$ & Pohanka et al., 2012 \\
\hline Acai PS & Enhances Th1 cell-related immunity & $\begin{array}{l}\text { Increased survival of mice infected with } F \\
\text { tularensis Schu S4 }\end{array}$ & Skyberg et al., 2012 \\
\hline \multicolumn{4}{|c|}{ SPECIFIC ANTIBODIES } \\
\hline $\begin{array}{l}\text { Monoclonal } \\
\text { antibodies }\end{array}$ & $\begin{array}{l}\text { Monoclonal antibodies against the LPS of } F \text {. } \\
\text { tularensis LVS }\end{array}$ & $\begin{array}{l}\text { Successfully used to treat LVS-induced } \\
\text { pneumonia; No effect on mice infected with F. } \\
\text { tularensis Schu S4 }\end{array}$ & $\begin{array}{l}\text { Lu et al., } 2007 \\
\text { Kirimanjeswara } \\
\text { et al., } 2008 \\
\text { Savitt et al., } 2009\end{array}$ \\
\hline
\end{tabular}


Table 1 | Continued

\begin{tabular}{|c|c|c|c|}
\hline Drug & Mechanism of action/target & Activity on F tularensis & References \\
\hline $\begin{array}{l}\text { Immune } \\
\text { sera }\end{array}$ & $\begin{array}{l}\text { Immune sera from mice infected via intra-nasal } \\
\text { Schu S4 challenge, and then treated with } \\
\text { levofloxacin } \\
\text { Sera containing abundant immunoglobulin } \\
\text { lgG2a }\end{array}$ & $\begin{array}{l}\text { Protective in mice infected with } F \text {. tularensis } \\
\text { Schu S4, when administered } 24 \mathrm{~h} \\
\text { post-infection }\end{array}$ & Klimpel et al., 2008 \\
\hline $\begin{array}{l}\text { Anti-MPF } \\
\text { lgM and lgG } \\
\text { antibodies }\end{array}$ & $\begin{array}{l}\text { Antibodies directed against the membrane } \\
\text { protein fraction (MFP) of F. tularensis Schu S4 }\end{array}$ & $\begin{array}{l}\text { Successfully used to treat mice infected with } \\
\text { F. tularensis Schu S4 when combined with } \\
\text { gentamicin }\end{array}$ & $\begin{array}{l}\text { Sutherland et al., } \\
2012\end{array}$ \\
\hline
\end{tabular}

\section{RECOMMENDED ANTIBIOTICS FOR TULARAEMIA TREATMENT (WHO GUIDELINES)}

According to the WHO guidelines (WHO, 2007), patients with severe tularaemia requiring hospitalization should receive parenteral administration of streptomycin or gentamicin. Both aminoglycosides display in vitro bactericidal activity against $F$. tularensis types A and B (Enderlin et al., 1994; Johansson et al., 2002; Kreizinger et al., 2013b). Aminoglycosides are associated with better outcomes and lower relapse rates (Enderlin et al., 1994). However, they can only be used parenterally, and they are occasionally associated with severe toxicity (especially ototoxicity and nephrotoxicity). Streptomycin is no longer available in many countries.

Fluoroquinolones are now advocated as first-line drugs in patients with clinical manifestations of mild to moderate severity (Ellis et al., 2002; Johansson et al., 2002). Ciprofloxacin may be given intravenously or by oral administration. In vitro, fluoroquinolones are highly active against $F$. tularensis subsp. holarctica (Syrjala et al., 1991; Scheel et al., 1993; Ikaheimo et al., 2000; Kreizinger et al., 2013b) and F. tularensis subsp tularensis (Johansson et al., 2002). Most data are restricted to ciprofloxacin, but levofloxacin, with an oral bioavailability of over $99 \%$ and daily administration, is an attractive alternative. Murine models have shown that the intraperitoneal administration of levofloxacin is $100 \%$ effective in preventing tularaemia after $F$. tularensis challenge (Klimpel et al., 2008). Intravenous administration of levofloxacin was also successful in treating human tularaemia cases, without relapse (Limaye and Hooper, 1999; Aranda, 2001). The bioavailability and efficacy of levofloxacin against $F$. tularensis was also studied in a common marmoset model of inhalational tularaemia that more faithfully mimics human tularaemia pneumonia (Nelson et al., 2010). Orally administered levofloxacin was highly effective in preventing the onset of acute inhalation tularaemia. Meric et al. also reported that moxifloxacin was as successful as ciprofloxacin for treatment of oropharyngeal tularaemia (Meric et al., 2008). Recently, Sutera et al. obtained in vitro mutants highly resistant to fluoroquinolones in different Francisella species (F. tularensis subsp. holarctica LVS, F. novicida, and $F$. philomiragia) by propagating strains with increasing concentration of ciprofloxacin. All high-level resistant mutants shared cross-resistance to other fluoroquinolones tested (moxifloxacine and levofloxacine), while some also revealed striking levels of cross-resistance to other clinically relevant antibiotic classes (the aminoglycoside gentamicin and tetracyclines) (Sutera et al., 2014).

Tetracyclines, especially doxycycline, are considered a potential alternative. However, due to its bacteriostatic activity, treatment must be administrated for a minimum of 2 weeks, and higher relapse rates have been reported as compared to fluoroquinolones (Enderlin et al., 1994). Tetracyclines are classically contraindicated in children less than 8 years old because of the risk of teeth discoloration, and in pregnant women because of foetal bone toxicity.

Whatever drug is administered, failures and relapses are often associated with delayed and/or insufficiently long treatment. Suppurated lymph nodes often need to be removed surgically to obtain clinical cure (Penn and Kinasewitz, 1987; Celebi et al., 2006).

\section{OTHER ANTIBIOTICS}

Most beta-lactams have no bacteriostatic activity against $F$. tularensis in vitro (Tarnvik and Chu, 2007). Although thirdgeneration cephalosporins (e.g., ceftriaxone) may be active in vitro against specific $F$. tularensis strains (Tomaso et al., 2005), therapeutic failures with these antibiotics are common (Cross and Jacobs, 1993). The ineffective activity of the beta-lactams against F. tularensis may be related both to the secretion of a class A betalactamase by this bacterium (Antunes et al., 2012) and to the poor penetration of these antibiotics in eukaryotic cells (Maurin et al., 2000). Thus, the beta-lactams are considered unreliable for tularaemia treatment.

It was first assumed that North American isolates of $F$. tularensis were naturally susceptible to macrolides, whereas most European strains were naturally resistant, including the vaccine strain F. tularensis LVS (Kudelina and Olsufiev, 1980). Later, Georgi et al. showed that $F$. tularensis subsp. holarctica isolates could be split into two biovars according to natural susceptibility or resistance to erythromycin. Strains with high-level resistance to erythromycin (i.e., biovar II) have spread to the northern and eastern parts of Europe (including Scandinavia, the Balkans, etc.), but also to Asia. The macrolide-susceptible strains (i.e., biovar I) predominate in western and southern Europe (France, Switzerland, Spain) and in North America. There is an overlap in the geographical distributions of both types of biovars, such as in Germany (Georgi et al., 2012). Nevertheless, failures and relapses in tularaemia patients treated with a macrolide have been 
reported worldwide, including in France (Maurin et al., 2011). Note that all isolates tested by Garcia del Blanco et al. during an outbreak in Spain were resistant to erythromycin (Garcia del Blanco et al., 2004). Thus, erythromycin is not a reliable option for treatment of tularaemia. Azithromycin is more active in vitro and has recently been proposed as a possible alternative in pregnant women in areas where the susceptible type B biovar I strains predominate (Dentan et al., 2013).

Although F. tularensis strains are susceptible to rifampicin in vitro (Tomaso et al., 2005), this antibiotic is not recommended for treatment of tularaemia because of a high risk of emergence of resistance during therapy. Chloramphenicol is less effective in vitro against $F$. tularensis, and it is associated with high relapse rates as well as bone marrow toxicity (Enderlin et al., 1994; Ikaheimo et al., 2000).

\section{NEW ANTIBIOTICS Ketolides}

The ketolide compounds (telithromycin and cethromycin) are a subclass of macrolide antibiotics, which have been designed to address the problem of macrolide resistance in respiratory pathogens such as Streptococcus pneumoniae. Telithromycin was more effective in vitro against French isolates of $F$. tularensis subsp. holarctica than erythromycin (Gestin et al., 2010). Cethromycin has comparable tissue penetration, pharmacokinetics and in vitro activity to telithromycin, especially against bacterial species responsible for community-acquired pneumonia (Hammerschlag and Sharma, 2008). Compared with other macrolides, these compounds have different advantages, including a higher affinity for the $50 \mathrm{~S}$ ribosomal subunit and a better stability at acidic pH (Hammerschlag and Sharma, 2008), which may partly explain the better activity in the intracellular environment of phagocytic cells where F. tularensis multiplies. Both telithromycin and cethromycin are potential alternatives for treatment of F. tularensis infection, but their clinical use in tularaemia patients has never been reported. Some authors have emphasized that cross-resistances between macrolide compounds may rapidly occur (Georgi et al., 2012).

\section{Glycylcyclines}

Tigecycline reaches high intracellular concentrations in tissues, macrophages and neutrophils, which makes this agent an interesting alternative for the treatment of intracellular pathogens (Pankey, 2005). Two papers report that F. tularensis strains isolated in Hungary and in Turkey were susceptible to tigecycline (Yesilyurt et al., 2011; Kreizinger et al., 2013a). These in vitro data suggest the potential usefulness of this antibiotic in tularaemia patients, but further in vivo experiments are needed for confirmation.

\section{New fluoroquinolones}

Ikäheimo et al. evaluated the in vitro antimicrobial susceptibility of 38 type B strains of $F$. tularensis isolated from human samples and dead wild animals. Ciprofloxacin, levofloxacin, grepafloxacin, and trovafloxacin had similar low MICs (Ikaheimo et al., 2000). Johansson et al. (Johansson et al., 2002) showed that gatifloxacin, grepafloxacin and sparfloxacin, were highly active against types
A and B strains of F. tularensis isolated in different regions of the US. An Austrian study tested the susceptibility of $50 \mathrm{~F}$. tularensis strains mainly isolated from hares to a wide range of antibiotics. The results showed low MIC values for all six fluoroquinolones tested (ciprofloxacin, levofloxacin, moxifloxacin, gatifloxacin, sparfloxacin) (Tomaso et al., 2005). The in vivo efficacy of gatifloxacin compared with ciprofloxacin and moxifloxacin was assessed in a BALB/c mouse model of $F$. tularensis Schu S4 infection. Lower mortality rates were found for gatifloxacin and moxifloxacin as compared to ciprofloxacin (Piercy et al., 2005; Steward et al., 2006).

\section{Linezolid}

Although linezolid is used for treatment of infections caused by Gram-positive bacteria, a Turkish study showed that F. tularensis could be susceptible to linezolid in vitro (Yesilyurt et al., 2011). However, linezolid was not effective against $F$. tularensis strains isolated in Hungary and North America (Johansson et al., 2002).

\section{Liposome delivery of antibiotics}

Treatment failures and relapses may also be related to the poor penetration and accumulation of antibiotics in tissues, especially in the subcellular compartment where $F$. tularensis multiplies. The liposome formulation of antibiotics is usually more effective than the conventional formulations against intracellular bacteria (Conley et al., 1997). Two studies have evaluated the liposome delivery of fluoroquinolones in order to reach high therapeutic doses of antibiotics within the intracellular compartment. One study demonstrated the efficacy of liposome-encapsulated ciprofloxacin, delivered to the lungs through aerosol inhalation, in mice with F. tularensis pneumonia (Conley et al., 1997). Another study showed that IV injection of liposome-encapsulated ciprofloxacin resulted in higher serum levels of this antibiotic, as well as increased drug retention in lungs, liver and spleen compared with the free drug. They also confirmed that aerosol inhalation of liposome-encapsulated ciprofloxacin, given for prophylactic or therapeutic purposes, provided mice with complete protection against a lethal $F$. tularensis pulmonary infection (Wong et al., 2003). The enhanced therapeutic efficacy can be attributable to the increased retention of ciprofloxacin in the lungs and to better intracellular delivery of ciprofloxacin by liposomes (Wong et al., 2003). The major drawback of this new therapeutic strategy is the need for more efficient techniques for preparing liposomal nanoparticles with great potential in targeting of antibiotics to bacteria and with high safety for humans (Hallaj-Nezhadi and Hassan, 2013).

\section{ANTIMICROBIAL PEPTIDES}

The human cathelicidin antimicrobial peptide LL-37 provides protection through host immunomodulation. It selectively regulates gene activation for expression of cytokines, chemokines and their receptor to control the recruitment of leukocytes to the infection site (Scott et al., 2002). It also activates or blocks TLR signaling (Into et al., 2010) and modulates apoptosis in neutrophils and epithelial cells (Barlow et al., 2011). Flick et al. evaluated the protective effect of LL-37 against F. tularensis LVS infection in cell culture and murine models. The objective was 
to overcome the immunosuppressive effects of $F$. tularensis infection by stimulating the innate immune response. Following LVS intranasal challenge in mice, the administration of LL-37 resulted in an increased production of IL-6, Il-12, IFN-gamma, and MCP1 , and thereby reduced proliferation of bacteria in the lungs 48-72 h post-challenge. However, LL-37 was only moderately and transiently effective, and mice ultimately succumbed to infection. The immune potentiating activity of LL-37 suggests it could be used as an adjunct therapy in the treatment of persistent forms of tularaemia (Flick-Smith et al., 2013).

\section{MODULATION OF THE INNATE IMMUNE RESPONSE AND SUPPRESSION OF $F$. TULARENSIS REPLICATION}

The pathogenicity of $F$. tularensis is correlated with its ability to evade or suppress the activation of the host immune system, and to replicate in phagocytic cells (Bosio et al., 2007). The rapid induction of the innate immune response is critical in controlling the early spread of intracellular pathogens. IFN-gamma and TNF-alpha can activate macrophages in vitro to restrict the replication of F. tularensis (Skyberg, 2013). IL-12 and Toll-like receptor (TLR) signaling are also involved in IFN-gamma and TNF-alpha production. One possible way to improve the efficacy of tularaemia treatment, and reduce the dosage and duration of the antibiotic treatment, is to combine cytokines with first-line antibiotic drugs. Indeed, different studies support the hypothesis that increasing the production of pro-inflammatory cytokines at the early stage of infection can be beneficial. This review focuses on immune agonists that, when administered after F. tularensis challenges, prevent or attenuate the consequences of infection and thus could be used as a curative therapeutic adjuvant in tularaemia patients. Prophylactic aspects have been presented in other reviews (KuoLee and Chen, 2007; Hepburn and Simpson, 2008; Skyberg, 2013). This approach has been used successfully by Pammit et al. (2004), who showed that although IL-12 alone was not able to reduce bacterial burdens in mice infected with F. novicida, intranasal IL-12 treatment decreased spleen and liver bacterial burdens more than 100-fold and lung bacterial burdens 50-fold when co-administrated with gentamicin. This combination improved clinical outcome and survival of animals when administrated early (8-24 h) after infection (Pammit et al., 2004). It should be mentioned that results obtained with $F$. novicida, a highly virulent bacterium in mice but non-virulent in humans, perhaps cannot be extrapolated to human infections caused by F. tularensis. Treatment of mice with IL-12 resulted in an early IFN-gamma response that allows the recruitment of neutrophils to the lungs during the first $24 \mathrm{~h}$ of infection. Neutrophils contribute to the rapid clearance of bacteria (Kirimanjeswara et al., 2008).

The activation of TLR signaling pathways in phagocytic cells has been reported to be a major defence mechanism against Francisella infection (Cowley and Elkins, 2011). Lembo et al. demonstrated that intranasal administration of a synthetic TLR4 agonist (aminoalkyl glucosaminide phosphatase, AGP) increased intrapulmonary cytokine and chemokine production. Mice treated with AGP after F. novicida inhalation exhibited reduced bacterial replication in the lung, liver and spleen, and increased survival (Lembo et al., 2008).
Administration of bacterial or oligonucleotide DNA containing $\mathrm{CpG}$ motifs to mice induced an immune activation and effective protection against a lethal parenteral challenge of these animals with F. tularensis LVS. This protection was highly dependent on B lymphocyte cells and INF-gamma production. Furthermore, animals surviving this lethal challenge developed a pathogen-specific secondary immunity (Elkins et al., 1999). More recently, these authors showed that DNA-related protection against LVS infection was dependent on TLR9, which is expressed intracellularly in murine macrophages, dendritic cells and B cells. Surprisingly, their data indicated that the role of B cells was not related to the action of CpG DNA motifs but to the anti-LPS antibody production by these cells in the peritoneal cavity. Instead, the production of soluble mediators by NK cells primed with CpG DNA in vivo contributed to DNA-mediated protection. Because murine NK cells do not express TLR9, in vivo activation was indirect and may have involved dendritic cells. In conclusion, this study suggested that indirect activation of NK cells by CpG DNA, via a TLR9-dependent pathway, resulted in the production of cytokines and NO, which controlled the intracellular growth of $F$. tularensis LVS in infected mice (Elkins et al., 2009). More recently, Rozak et al. conducted the same experiment with the more virulent SCHU4 strain. Their results revealed that CpG DNA failed to positively affect the course of F. tularensis SCHU4 pneumonic infection in mice (Rozak et al., 2010). These contradictory data emphasize the need for evaluation of both type A and type B F. tularensis strains in animal models.

Pyles et al. (2010) evaluated the effect of poly(I:C) (polyinosine polycytosine), a synthetic double-stranded RNA analog that stimulates TLR3, as a novel treatment for F. tularensis respiratory infection. TLR3 is expressed by respiratory epithelial cells and macrophages and can trigger the induction of the host innate immune response, including TNF-alpha, IFN-gamma, IL8 , and IL-6 secretion. Intranasal administration of poly(I:C) in mice induced an early and effective innate immune response by increasing the secretion of cytokines and the neutrophil influx in the lungs. This effect was transient but prolonged the survival of animals. Furthermore, poly(I:C) increased cytokine secretion by human monocyte-derived macrophages and significantly reduced intracellular replication of $F$. tularensis in these cells. Thus, Poly(I:C) may be a useful additive therapeutic agent in patients infected by F. tularensis aerosols.

Galantamine is an inhibitor of acetyl-cholinesterase used for treatment of Alzheimer's disease. Galantamine has also been reported to modify TNF-alpha levels through stimulation of the cholinergic anti-inflammatory pathway (Liu et al., 2010). The resolution of tularaemia infection is mediated by the production of IFN-gamma and the activation of macrophages, resulting in an increased production of nitric oxide synthase and killing of F. tularensis by these phagocytic cells. Pohanka et al. (2012) showed that galantamine could significantly influence the immune response via the cholinergic anti-inflammatory pathway by up-regulating IFN-gamma production and down-regulating IL-6 production. Mice treated with galantamine showed lower mortality rates when infected with $F$. tularensis.

Skyberg et al. (2012) reported that a natural polysaccharide extract isolated from Acai berry (Acai PS, derived from 
the berry of the palm tree Euterpe oleracea in South America) enhanced the clearance of F. tularensis LVS and Schu4 from human macrophages when co-cultured with autologous natural killer cells. Impaired replication of F. tularensis in human macrophages was related to increased production of IFN-gamma by NK cells. Intranasal administration of Acai PS to mice immediately, 24 or $48 \mathrm{~h}$ after a Schu 4 aerosol challenge resulted in survival rates of 73, 60, and 33\%, respectively. In both human and murine cells, Acai PS enhanced Th1 cell-mediated immunity. Acai PS is currently the most active immunotherapeutic agent reported in the literature for treatment of experimental pneumonia caused by type A F. tularensis.

The activation of the innate immunity may help antibiotherapy to eradicate F. tularensis in infected patients. However, activation of the innate immunity may lead to higher inflammatory response and injury of the lung tissue. The timing of administration of proinflammatory treatments requires careful management, since there is a danger that their use may exacerbate the symptoms of disease in infected patients (D'Elia et al., 2013). If treatment is initiated either just before or the same time as infection, then the induction of proinflammatroy cytokines by stimulatory molecules has beneficial effects on host survival as shown with CpG oligonucleotides (Elkins et al., 1999). Moreover, the mode of administration of such combination in humans remains to be determined. The small window for such treatment greatly limits application of this adjunctive therapy in clinical practice. It has been observed that the use of proinflammatory cytokines themselves such as IL-1 $\beta$ cause side effects, including generalized fatigue, headache, nausea, vomiting, myalgia, and arthralgia (Crown et al., 1991). By modulating rather than up-regulating the immune response via mechanisms such as cholinergic anti-inflammatory pathways (example of galantamine, Pohanka et al., 2012), the damaging cytokine storms can be prevented. This may allow a longer window for diagnosis and treatment (D'Elia et al., 2013) but these strategies require more in vivo investigation for further evaluation of their efficacy and tolerance.

\section{ADMINISTRATION OF SPECIFIC ANTIBODIES}

Before the antibiotic era, patients suffering from tularaemia were successfully treated with xenogeneic immune sera (Elkins et al., 2007). The role of antibodies for protection against infections caused by intracellular pathogens has long been controversial, but recent studies have shown that they contribute to protection against $F$. tularensis infection (Kirimanjeswara et al., 2008; Skyberg, 2013). Kirimanjeswara et al. showed that passive intraperitoneal transfer of immune serum in mice provided complete protection against intranasal challenge with lethal doses of LVS, even when administrated $24-48 \mathrm{~h}$ post-infection. These results indicate that serum antibodies may be used for both prophylactic and therapeutic purposes (Kirimanjeswara et al., 2007). Another study showed that monoclonal antibodies against the LPS of F. tularensis LVS could be successfully used to treat LVS-induced pneumonia (Lu et al., 2007). Unfortunately, these promising results could not be reproduced when using a F. tularensis type A strain. Anti-LVS antibodies failed to protect mice challenged with F. tularensis Schu S4. One explanation could be that the
Schu S4 strain completely abolished the inflammatory responses that are required for efficient antibody-mediated bacterial clearance (Kirimanjeswara et al., 2008). Another study also showed relative efficacy for immunotherapy using monoclonal antibodies (MAbs). Most particularly, MAbs directed against LVS components could confer protection in mice challenged with this strain. However, MAbs were much less active in protecting mice challenged with the type A F. tularensis Schu S4 strain (Savitt et al., 2009). Klimpel et al. showed that mice infected via intra-nasal Schu S4 challenge and then treated with levofloxacin developed protective immunity. Interestingly, sera from these mice were protective when passively transferred to naive mice, even when administered $24 \mathrm{~h}$ post-infection. In these protective sera, the most abundant immunoglobulin class was IgG2a, suggesting that a Th1-type immune response was predominant (Klimpel et al., 2008). Sutherland et al. showed that the passive transfer of antibodies directed against the membrane protein fraction (MFP) of F. tularensis Schu S4, to mice infected with the same strain, resulted in complete protection when combined with gentamicin treatment. These sera contained high titers of anti-MPF IgM and IgG antibodies, comparable to those observed during natural infection. Post-exposure immunization with MPF antigens was an effective means of enhancing the activity of conventional antimicrobial therapy for pneumonic tularaemia (Sutherland et al., 2012). Immune sera are probably not effective enough to treat severe pulmonary tularaemia cases, but could be used in combination with antibiotics to obtain a more rapid response to treatment.

\section{CONCLUSION}

The fear of a bioterrorism attack scenario after the September 11, 2001, incident has renewed the medical and scientific interest in F. tularensis, a class A bioterrorism agent. However, only limited progress has been made in the development of new tularaemia therapies. Due to the lack of an effective and safe vaccine, antibiotics remain the only strategies available for prophylaxis and treatment of tularaemia. New therapeutic alternatives are needed because of the potential toxicity of first-line drugs, especially in children and pregnant women; high rates of treatment relapses and failures, especially for severe and/or suppurated forms of the disease; and the possible use of antibiotic-resistant strains in the context of biological threat. Among the new therapeutic strategies, no published study present large-scale screening of new molecules for inhibitory potential of $F$. tularensis growth. There is no more data in the literature concerning the use of bacteriophage against Francisella. Activation of the innate immune system can enhance resistance of the host to F. tularensis infection and could help clearance of the bacteria and disease cure when combined with the administration of antibiotics. Promising results have been obtained in animal models, but this strategy only applies if the involved F. tularensis strain is still susceptible to antibiotics, which may not be the case in the context of bioterrorism. Several virulence factors have been identified such as the pathogenicity island but also genes encoding type IV pili, a type II secretion system, a type VI secretion system, iron acquisition systems (Larsson et al., 2005). Bacterial virulence factors have been increasingly regarded as attractive targets for development of 
novel antibacterial agents. This type of approach has for example been used in Salmonella enterica serovar Typhimurium and led to the identification of Cytosporone B, an inhibitor of the Type III Secretion System of Salmonella as novel antibacterial agent (Li et al., 2013). Finally, it should be remembered that new antiinfective strategy effective against type B strains may not apply to the more severe infections caused by type A strain.

\section{REFERENCES}

Antunes, N. T., Frase, H., Toth, M., and Vakulenko, S. B. (2012). The class A beta-lactamase FTU-1 is native to Francisella tularensis. Antimicrob. Agents Chemother. 56, 666-671. doi: 10.1128/AAC.05305-11

Aranda, E. A. (2001). Treatment of tularemia with levofloxacin. Clin. Microbiol. Infect. 7, 167-168. doi: 10.1046/j.1469-0691.2001.00234.x

Barlow, P. G., Svoboda, P., Mackellar, A., Nash, A. A., York, I. A., Pohl, J., et al. (2011). Antiviral activity and increased host defense against influenza infection elicited by the human cathelicidin LL-37. PLOS ONE 6:e25333. doi: 10.1371/journal.pone.0025333

Bosio, C. M., Bielefeldt-Ohmann, H., and Belisle, J. T. (2007). Active suppression of the pulmonary immune response by Francisella tularensis Schu4. J. Immunol. 178, 4538-4547.

Celebi, G., Baruonu, F., Ayoglu, F., Cinar, F., Karadenizli, A., Ugur, M. B., et al. (2006). Tularemia, a reemerging disease in northwest Turkey: epidemiological investigation and evaluation of treatment responses. Jpn. J. Infect. Dis. 59, 229-234.

Chitadze, N., Kuchuloria, T., Clark, D. V., Tsertsvadze, E., Chokheli, M., Tsertsvadze, N., et al. (2009). Water-borne outbreak of oropharyngeal and glandular tularemia in Georgia: investigation and follow-up. Infection 37, 514-521. doi: 10.1007/s15010-009-8193-5

Conley, J., Yang, H., Wilson, T., Blasetti, K., Di Ninno, V., Schnell, G., et al. (1997). Aerosol delivery of liposome-encapsulated ciprofloxacin: aerosol characterization and efficacy against Francisella tularensis infection in mice. Antimicrob. Agents Chemother. 41, 1288-1292.

Cowley, S. C., and Elkins, K. L. (2011). Immunity to francisella. Front. Microbiol. 2:26. doi: 10.3389/fmicb.2011.00026

Cross, J. T., and Jacobs, R. F. (1993). Tularemia: treatment failures with outpatient use of ceftriaxone. Clin. Infect. Dis. 17, 976-980. doi: 10.1093/clinids/17. 6.976

Crown, J., Jakubowski, A., Kemeny, N., Gordon, M., Gasparetto, C., Wong, G., et al. (1991). A phase I trial of recombinant human interleukin-1 beta alone and in combination with myelosuppressive doses of 5-fluorouracil in patients with gastrointestinal cancer. Blood 78, 1420-1427.

D’Elia, R. V., Harrison, K., Oyston, P. C., Lukaszewski, R. A., and Clark, G. C. (2013). Targeting the "cytokine storm" for therapeutic benefit. Clin. Vaccine Immunol. 20, 319-327. doi: 10.1128/CVI.00636-12

Dentan, C., Pavese, P., Pelloux, I., Boisset, S., Brion, J. P., Stahl, J. P., et al. (2013). Treatment of tularemia in pregnant woman, France. Emerging Infect. Dis. 19, 996-998. doi: 10.3201/eid1906.130138

Elkins, K. L., Colombini, S. M., Krieg, A. M., and De Pascalis, R. (2009). NK cells activated in vivo by bacterial DNA control the intracellular growth of Francisella tularensis LVS. Microbes Infect. 11, 49-56. doi: 10.1016/j.micinf.2008.10.005

Elkins, K. L., Cowley, S. C., and Bosio, C. M. (2007). Innate and adaptive immunity to Francisella. Ann. N.Y. Acad. Sci. 1105, 284-324. doi: 10.1196/annals. 1409.014

Elkins, K. L., Rhinehart-Jones, T. R., Stibitz, S., Conover, J. S., and Klinman, D. M. (1999). Bacterial DNA containing CpG motifs stimulates lymphocytedependent protection of mice against lethal infection with intracellular bacteria. J. Immunol. 162, 2291-2298.

Ellis, J., Oyston, P. C., Green, M., and Titball, R. W. (2002). Tularemia. Clin. Microbiol. Rev. 15, 631-646. doi: 10.1128/CMR.15.4.631-646.2002

Enderlin, G., Morales, L., Jacobs, R. F., and Cross, J. T. (1994). Streptomycin and alternative agents for the treatment of tularemia: review of the literature. Clin. Infect. Dis. 19, 42-47. doi: 10.1093/clinids/19.1.42

Evans, M. E., Gregory, D. W., Schaffner, W., and McGee, Z. A. (1985). Tularemia: a 30-year experience with 88 cases. Medicine (Baltimore) 64, 251-269. doi: 10.1097/00005792-198507000-00006

Flick-Smith, H. C., Fox, M. A., Hamblin, K. A., Richards, M. I., Jenner, D. C., Laws, T. R., et al. (2013). Assessment of antimicrobial peptide LL-37 as a post-exposure therapy to protect against respiratory tularemia in mice. Peptides 43, 96-101. doi: 10.1016/j.peptides.2013.02.024

Garcia del Blanco, N., Gutierrez Martin, C. B., de la Puente Redondo, V. A., and Rodriguez Ferri, E. F. (2004). In vitro susceptibility of field isolates of Francisella tularensis subsp. holarctica recovered in Spain to several antimicrobial agents. Res. Vet. Sci. 76, 195-198. doi: 10.1016/j.rvsc.2003.12.002

Georgi, E., Schacht, E., Scholz, H. C., and Splettstoesser, W. D. (2012). Standardized broth microdilution antimicrobial susceptibility testing of Francisella tularensis subsp. holarctica strains from Europe and rare Francisella species. J. Antimicrob. Chemother. 67, 2429-2433. doi: 10.1093/jac/dks238

Gestin, B., Valade, E., Thibault, F., Schneider, D., and Maurin, M. (2010). Phenotypic and genetic characterization of macrolide resistance in Francisella tularensis subsp. holarctica biovar I. J. Antimicrob. Chemother. 65, 2359-2367. doi: $10.1093 /$ jac/dkq315

Gill, V., and Cunha, B. A. (1997). Tularemia pneumonia. Semin. Respir. Infect. 12, 61-67.

Kirimanjeswara, G. S., Golden, J. M., Bakshi, C. S., and Metzger, D. W. (2007). Prophylactic and therapeutic use of antibodies for protection against respiratory infection with Francisella tularensis. J. Immunol. 179, 532-539.

Hallaj-Nezhadi, S., and Hassan, M. (2013). Nanoliposome-based antibacterial drug delivery. Drug Deliv. doi: 10.3109/10717544.2013.863409. [Epub ahead of print].

Hammerschlag, M. R., and Sharma, R. (2008). Use of cethromycin, a new ketolide, for treatment of community-acquired respiratory infections. Expert Opin. Investig. Drugs 17, 387-400. doi: 10.1517/13543784.17.3.387

Hauri, A. M., Hofstetter, I., Seibold, E., Kaysser, P., Eckert, J., Neubauer, H., et al. (2010). Investigating an airborne tularemia outbreak, Germany. Emerging Infect. Dis. 16, 238-243. doi: 10.3201/eid1602.081727

Hepburn, M. J., and Simpson, A. J. (2008). Tularemia: current diagnosis and treatment options. Expert Rev. Anti Infect. Ther. 6, 231-240. doi: 10.1586/14787210.6.2.231

Ikaheimo, I., Syrjala, H., Karhukorpi, J., Schildt, R., and Koskela, M. (2000). In vitro antibiotic susceptibility of Francisella tularensis isolated from humans and animals. J. Antimicrob. Chemother. 46, 287-290. doi: 10.1093/jac/46.2.287

Into, T., Inomata, M., Shibata, K., and Murakami, Y. (2010). Effect of the antimicrobial peptide LL-37 on Toll-like receptors 2-, 3- and 4-triggered expression of IL-6, IL-8 and CXCL10 in human gingival fibroblasts. Cell. Immunol. 264, 104-109. doi: 10.1016/j.cellimm.2010.05.005

Johansson, A., Urich, S. K., Chu, M. C., Sjostedt, A., and Tarnvik, A. (2002). In vitro susceptibility to quinolones of Francisella tularensis subspecies tularensis. Scand. J. Infect. Dis. 34, 327-330. doi: 10.1080/00365540110080773

Kirimanjeswara, G. S., Olmos, S., Bakshi, C. S., and Metzger, D. W. (2008). Humoral and cell-mediated immunity to the intracellular pathogen Francisella tularensis. Immunol. Rev. 225, 244-255. doi: 10.1111/j.1600-065X.2008.00689.x

Klimpel, G. R., Eaves-Pyles, T., Moen, S. T., Taormina, J., Peterson, J. W., Chopra, A. K., et al. (2008). Levofloxacin rescues mice from lethal intra-nasal infections with virulent Francisella tularensis and induces immunity and production of protective antibody. Vaccine 26, 6874-6882. doi: 10.1016/j.vaccine.2008.09.077

Kosker, M., Sener, D., Kilic, O., Akil, F., Yilmaz, M., Ozturk, O., et al. (2013). A case of oculoglandular tularemia resistant to medical treatment. Scand. J. Infect. Dis. 45, 725-727. doi: 10.3109/00365548.2013.796089

Kreizinger, Z., Hornok, S., Dan, A., Hresko, S., Makrai, L., Magyar, T., et al. (2013a). Prevalence of Francisella tularensis and francisella-like endosymbionts in the tick population of hungary and the genetic variability of francisella-like agents. Vector Borne Zoonotic Dis. 13, 160-163. doi: 10.1089/vbz.2012.1065

Kreizinger, Z., Makrai, L., Helyes, G., Magyar, T., Erdelyi, K., and Gyuranecz, M. (2013b). Antimicrobial susceptibility of Francisella tularensis subsp. holarctica strains from Hungary, Central Europe. J. Antimicrob. Chemother. 68, 370-373. doi: 10.1093/jac/dks399

Kudelina, R. I., and Olsufiev, N. G. (1980). Sensitivity to macrolide antibiotics and lincomycin in Francisella tularensis holarctica. J. Hyg. Epidemiol. Microbiol. Immunol. 24, 84-91.

KuoLee, R., and Chen, W. (2007). Vaccines and therapeutic agents for tularemia. Expert Opin. Ther. Patents 17, 267-275. doi: 10.1517/13543776.17.3.267

Larsson, P., Oyston, P. C., Chain, P., Chu, M. C., Duffield, M., Fuxelius, H. H., et al. (2005). The complete genome sequence of Francisella tularensis, the causative agent of tularemia. Nat. Genet. 37, 153-159. doi: 10.1038/ng1499

Lembo, A., Pelletier, M., Iyer, R., Timko, M., Dudda, J. C., West, T. E., et al. (2008). Administration of a synthetic TLR4 agonist protects mice from pneumonic tularemia. J. Immunol. 180, 7574-7581. 
Li, J., Lv, C., Sun, W., Li, Z., Han, X., Li, Y., and Shen, Y. (2013). Cytosporone $\mathrm{B}$, an inhibitor of the type III secretion system of Salmonella enterica serovar Typhimurium. Antimicrob. Agents Chemother. 57, 2191-2198. doi: 10.1128/AAC.02421-12

Limaye, A. P., and Hooper, C. J. (1999). Treatment of tularemia with fluoroquinolones: two cases and review. Clin. Infect. Dis. 29, 922-924. doi: $10.1086 / 520458$

Liu, Z. H., Ma, Y. F., Wu, J. S., Gan, J. X., Xu, S. W., and Jiang, G. Y. (2010). Effect of cholinesterase inhibitor galanthamine on circulating tumor necrosis factor alpha in rats with lipopolysaccharide-induced peritonitis. Chin. Med. J. 123, 1727-1730.

Lu, Z., Roche, M. I., Hui, J. H., Unal, B., Felgner, P. L., Gulati, S., et al.. (2007). Generation and characterization of hybridoma antibodies for immunotherapy of tularemia. Immunol. Lett. 112, 92-103. doi: 10.1016/j.imlet. 2007.07.006

Maurin, M., Mersali, N. F., and Raoult, D. (2000). Bactericidal activities of antibiotics against intracellular Francisella tularensis. Antimicrob. Agents Chemother. 44, 3428-3431. doi: 10.1128/AAC.44.12.3428-3431.2000

Maurin, M., Pelloux, I., Brion, J. P., Del Bano, J. N., and Picard, A. (2011). Human tularemia in France, 2006-2010. Clin. Infect. Dis. 53, e133-e141. doi: 10.1093/cid/cir612

Meric, M., Willke, A., Finke, E. J., Grunow, R., Sayan, M., Erdogan, S., et al. (2008). Evaluation of clinical, laboratory, and therapeutic features of 145 tularemia cases: the role of quinolones in oropharyngeal tularemia. APMIS 116, 66-73. doi: 10.1111/j.1600-0463.2008.00901.x

Nelson, M., Lever, M. S., Dean, R. E., Pearce, P. C., Stevens, D. J., and Simpson, A. J. (2010). Bioavailability and efficacy of levofloxacin against Francisella tularensis in the common marmoset (Callithrix jacchus). Antimicrob Agents Chemother 54, 3922-3926. doi: 10.1128/AAC.00390-10

Scott, M. G., Davidson, D. J., Gold, M. R., Bowdish, D., and Hancock, R. E. (2002). The human antimicrobial peptide LL-37 is a multifunctional modulator of innate immune responses. J. Immunol. 169, 3883-3891.

Pammit, M. A., Budhavarapu, V. N., Raulie, E. K., Klose, K. E., Teale, J. M., and Arulanandam, B. P. (2004). Intranasal interleukin-12 treatment promotes antimicrobial clearance and survival in pulmonary Francisella tularensis subsp. novicida infection. Antimicrob. Agents Chemother. 48, 4513-4519. doi: 10.1128/AAC.48.12.4513-4519.2004

Pankey, G. A. (2005). Tigecycline. J. Antimicrob. Chemother. 56, 470-480. doi: $10.1093 / \mathrm{jac} / \mathrm{dki} 248$

Penn, R. L., and Kinasewitz, G. T. (1987). Factors associated with a poor outcome in tularemia. Arch. Intern. Med. 147, 265-268. doi: 10.1001/archinte.1987.00370020083041

Perez-Castrillon, J. L., Bachiller-Luque, P., Martin-Luquero, M., Mena-Martin, F. J., and Herreros, V. (2001). Tularemia epidemic in northwestern Spain: clinical description and therapeutic response. Clin. Infect. Dis. 33, 573-576. doi: $10.1086 / 322601$

Piercy, T., Steward, J., Lever, M. S., and Brooks, T. J. (2005). In vivo efficacy of fluoroquinolones against systemic tularemia infection in mice. J. Antimicrob. Chemother. 56, 1069-1073. doi: 10.1093/jac/dki359

Pohanka, M., Pavlis, O., and Pikula, J. (2012). Galantamine effect on tularemia pathogenesis in a BALB/c mouse model. Iran. Biomed. J. 16, 156-161.

Pyles, R. B., Jezek, G. E., and Eaves-Pyles, T. D. (2010). Toll-like receptor 3 agonist protection against experimental Francisella tularensis respiratory tract infection. Infect. Immun. 78, 1700-1710. doi: 10.1128/IAI.00736-09

Rozak, D. A., Gelhaus, H. C., Smith, M., Zadeh, M., Huzella, L., Waag, D., et al. (2010). CpG oligodeoxyribonucleotides protect mice from Burkholderia pseudomallei but not Francisella tularensis Schu S4 aerosols. J. Immune Based Ther. Vaccines 8:2. doi: 10.1186/1476-8518-8-2

Savitt, A. G., Mena-Taboada, P., Monsalve, G. and Benach, J. L. (2009). Francisella tularensis infection-derived monoclonal antibodies provide detection, protection, and therapy. Clin. Vaccine Immunol. 16, 414-422. doi: 10.1128/CVI. 00362-08
Scheel, O., Hoel, T., Sandvik, T., and Berdal, B. P. (1993). Susceptibility pattern of Scandinavian Francisella tularensis isolates with regard to oral and parenteral antimicrobial agents. APMIS 101, 33-36. doi: 10.1111/j.16990463.1993.tb00077.x

Skyberg, J. A. (2013). Immunotherapy for tularemia. Virulence 4, 859-870. doi: 10.1371/journal.ppat.1002587

Skyberg, J. A., Rollins, M. F., Holderness, J. S., Marlenee, N. L., Schepetkin, I. A., Goodyear, A., et al. (2012). Nasal Acai polysaccharides potentiate innate immunity to protect against pulmonary Francisella tularensis and Burkholderia pseudomallei Infections. PLoS Pathog. 8:e1002587. doi: 10.1371/journal.ppat.1002587

Steward, J., Piercy, T., Lever, M. S., Simpson, A. J., and Brooks, T. J. (2006). Treatment of murine pneumonic Francisella tularensis infection with gatifloxacin, moxifloxacin or ciprofloxacin. Int. J. Antimicrob. Agents 27, 439-443. doi: 10.1016/j.ijantimicag.2006.02.006

Sutera, V., Levert, M., Burmeister, W. P., Schneider, D., and Maurin, M. (2014). Evolution toward high-level fluoroquinolone resistance in Francisella species. J. Antimicrob. Chemother. 69, 101-110. doi: 10.1093/jac/dkt321

Sutherland, M. D., Goodyear, A. W., Troyer, R. M., Chandler, J. C., Dow, S. W., and Belisle, J. T. (2012). Post-exposure immunization against Francisella tularensis membrane proteins augments protective efficacy of gentamicin in a mouse model of pneumonic tularemia. Vaccine 30, 4977-4982. doi: 10.1016/j.vaccine.2012.05.037

Syrjala, H., Schildt, R., and Raisainen, S. (1991). In vitro susceptibility of Francisella tularensis to fluoroquinolones and treatment of tularemia with norfloxacin and ciprofloxacin. Eur. J. Clin. Microbiol. Infect. Dis. 10, 68-70. doi: 10.1007/BF01964409

Tarnvik, A., and Chu,. M. C. (2007). New approaches to diagnosis and therapy of tularemia. Ann. N.Y. Acad. Sci. 1105, 378-404. doi: 10.1196/annals. 1409.017

Tomaso, H., Al Dahouk, S. Hofer, E., Splettstoesser, W. D., Treu, T. M., Dierich, M. P., et al. (2005). Antimicrobial susceptibilities of Austrian Francisella tularensis holarctica biovar II strains. Int. J. Antimicrob. Agents 26, 279-284. doi: 10.1016/j.ijantimicag.2005.07.003

Wong, J. P., Yang, H., Blasetti, K. L., Schnell, G., Conley, J., and Schofield, L. N. (2003). Liposome delivery of ciprofloxacin against intracellular Francisella tularensis infection. J. Control. Release 92, 265-273. doi: 10.1016/S01683659(03)00358-4

World Health Organisation. (2007). WHO Guidelines on Tularaemia. Geneva: World Health Organization.

Yesilyurt, M., Kilic, S., Celebi, B., Celik, M., Gul, S., Erdogan, F., et al. (2011). Antimicrobial susceptibilities of Francisella tularensis subsp. holarctica strains isolated from humans in the Central Anatolia region of Turkey. J. Antimicrob. Chemother. 66, 2588-2592. doi: 10.1093/jac/dkr338

Conflict of Interest Statement: The authors declare that the research was conducted in the absence of any commercial or financial relationships that could be construed as a potential conflict of interest.

Received: 12 January 2014; paper pending published: 17 February 2014; accepted: 13 March 2014; published online: 28 March 2014.

Citation: Boisset S, Caspar Y, Sutera V and Maurin M (2014) New therapeutic approaches for treatment of tularaemia: a review. Front. Cell. Infect. Microbiol. 4:40. doi: $10.3389 /$ fimb.2014.00040

This article was submitted to the journal Frontiers in Cellular and Infection Microbiology.

Copyright (C) 2014 Boisset, Caspar, Sutera and Maurin. This is an open-access article distributed under the terms of the Creative Commons Attribution License (CC BY). The use, distribution or reproduction in other forums is permitted, provided the original author(s) or licensor are credited and that the original publication in this journal is cited, in accordance with accepted academic practice. No use, distribution or reproduction is permitted which does not comply with these terms. 